\title{
し尿処理施設へのサポニン添加実験
}

\author{
竺 文 彦 ${ }^{*}$. 村 井 英 雄 ${ }^{* *}$. 松 本 和 夫 ${ }^{* * *}$
}

1.はじめに

サポニンは，非糖部のゲニン（アグリコン）と糖部 からなる配糖体で，おすに植物に含まれる天然の界面 活性斉の総称であるが, 鎮静, 沈痛, 強心, 抗ストレ ス作用などさまざまな生理的な活性作用があるため， これまで医薬品をはじめとする用途に用いられてきて いる.

排水処理の分野においては, 活性污泥法などの生物 処理において，処理性能の改善などのために添加剤が 用いられる場合があり，一般的には微生物製剂を用い ることが多い，サポニンの添加の場合には，直接微生 物を添加するという考え方とは異なっているが，微生 物の生理作用を活性化すると考えられる効果により処 理性能や污泥の性状を改善することが可能であるため, 基礎的な検討がなされており ${ }^{1)}$ ，筆者らは，これまで 室内実験や実施設における実験的検討を加えてきた ${ }^{2) \sim 51}$

ここでは，添加剤を用いることが比較的多いし尿処 理施設における高負荷条件下でのサポニン添加実験に ついて報告する。

\section{2. Јし尿処理施設に関する実験}

Jし尿処理施設では, 湿式酸化処理の後活性污泥法 による処理を行っており,この活性污泥曝気槽にサポ ニンを添加し，高負荷条件とした場合の処理状況につ
いて検討した。

\section{1 Jし尿処理施設の概要}

実験を行った Jし尿処理施設の処理方法としては， 湿式酸化処理の後, 活性污泥処理を行うあのであり, 施設の処理能力は $400 \mathrm{k} \ell /$ 日で, 処理性能では, 生し 尿（净化槽污泥を含む）の $\mathrm{S} \mathrm{S} 30,000 \mathrm{mg} / \ell, \mathrm{COD}_{\mathrm{cr}}$ $35,000 \mathrm{mg} / \ell$ に対し，放流水のBOD20mg / $\ell$ 以下, S S60mg / $\ell$ 以下, 透視度10以上とされている.

処理施設フローシートを図ー 1 に示す. 実際の水質 については，投入負荷量の変動や，し尿之浄化槽污泥 との比率によって変化するが, 平均的な BODの值で は, 生し尿7,000 8,000mg/ $\ell$, 湿式酸化処理水 6,000 $\sim 7,000 \mathrm{mg} / \ell$, 放流水 $10 \mathrm{mg} / \ell$ 程度である. 1988年 10 月から1989年 4 月までの月 2 回の定期的な水質試験 における $\mathrm{BOD}, \mathrm{COD}_{\mathrm{Mn}}$ の平均值を表 1 に示す. 表 1 において, 湿式酸化処理のCODの除去率は75\%と高 いのに対し，BODの除去率は16\%となっている。B OD除去率が低くなっているが，これは湿式酸化処理 によって固形の有機物などが分解し，溶解性のB OD 物質に変化しているために，見かけ上の除去率が低く

表 $1 \mathrm{~J}$ 処理施設の平均的水質

\begin{tabular}{lccc} 
& & & \multicolumn{2}{c}{$(\mathrm{mg} / \mathrm{l})$} \\
\hline & 生し尿 & 湿式酸化処理水 & 放流水 \\
\hline $\mathrm{BOD}$ & 8,350 & 7,010 & 7 \\
\hline $\mathrm{COD}_{\mathrm{Mn}}$ & 5,187 & 1,274 & 40 \\
\hline
\end{tabular}

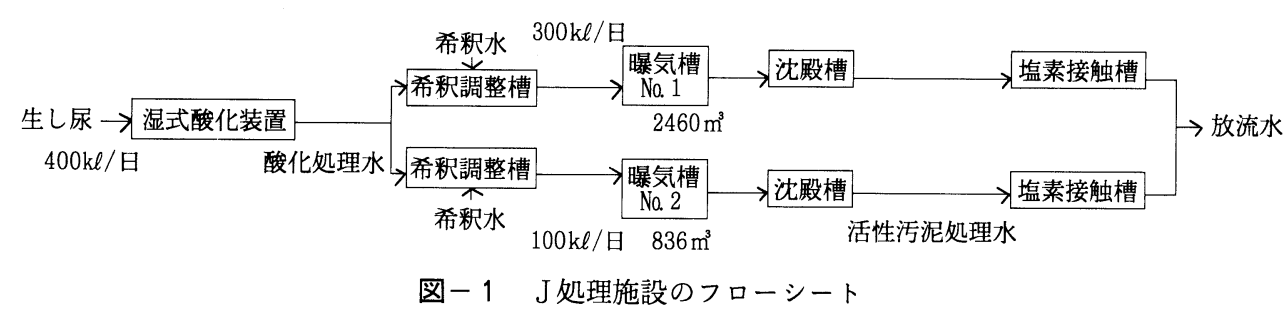

*龍谷大学理工学部助教授 Fumihiko JIKU **袋井衛生センター所長 Hideo MURAI***袋井衛生センター主任技師 Kazuo MATSUMOTO 
なっているためと思われる

湿式酸化処理水は，2 系列に分けられた後，希釈調 整槽において13〜15倍に希釈され，機械曝気式の活性 污泥法により処理される. 平均的な処理量は, N ‥ 1 系 列が（湿式酸化処理水として） $300 \mathrm{k} \ell /$ 日, No. 2 系列 が $100 \mathrm{k} \ell /$ 日である.実験はN0. 2 系列のみを対象とし， №. 2 の曝気槽にサポニンを添加することとした. №.2 の曝気槽の容量は, $836 \mathrm{~m}^{3}$ であり，およそ $1.1 \mathrm{Q}$ の污泥 返送量も含めた曝気槽流入水の曝気時間は，約 7 時間 となる。

\section{2 サポニン添加実験}

(1)実験方法

湿式酸化処理後のNNo.2 活性污泥曝気槽にサポニンを 添加し，処理性能や污泥の状況などについて検討を行っ た．実験期間は，1989年 2 月から 4 月までである。実 験期間中の湿式酸化処理水（曝気槽に対する流入原水） 量と希釈水量の状況などを表 2 に示す. 実験では, 湿 式酸化処理水量として $90 \mathrm{~m}^{3}$ から $120 \mathrm{~m}^{3}$ まで 4 段階で流

表 2 実験期間における曝気槽への流入水量

\begin{tabular}{|c|c|c|c|c|}
\hline RUN & 期 間 & $\begin{array}{c}\text { 湿式酸化処理水量 } \\
\left(\mathrm{m}^{3} / \text { 日 }\right)\end{array}$ & $\begin{array}{l}\text { 希釈水量 } \\
\left(\mathrm{m}^{3} / \text { 日) }\right.\end{array}$ & $\begin{array}{l}\text { 返送污泥量 } \\
\left(\mathrm{m}^{3} / \text { 日 }\right)\end{array}$ \\
\hline I & $2 / 6-3 / 19$ & 90 & 1,200 & $1,330 \sim 1,430$ \\
\hline II & $3 / 20-3 / 26$ & 100 & 1,200 & 1,430 \\
\hline III & $3 / 27-4 / 10$ & 110 & 1,200 & 1,430 \\
\hline IV & $4 / 11-4 / 16$ & 120 & 1,300 & 1,530 \\
\hline
\end{tabular}

入負荷を増加させてゆき，処理に与える影響について 検討した. 曝気槽のML S S は，およそ $3,000 \mathrm{mg} / \ell$ と し，サポニン投入量は，サポニン原液の50倍希釈液を $43 \ell /$ 日し，定量ポンプで滴下した．ただし実験期 間IVでは，サポニン投入量を $1 / 2$ に削減するため，原液 の希釈率を100倍とした．使用したサポニン原液は， トリテルペノイド系のキラヤサポニンの 4 \%溶液であ る.

(2)実験結果

曝気槽のS Vの測定結果を図ー 2 に示す．実験開始 時にSVは80程度であったが徐々に低下していき，お よそ 2 週間程度で50台となった。 また，負荷をあげた 実験後半の 4 月の段階ではS Vの值は不安定となり， やや上昇の傾向にある

処理水（沈殿槽流出水）の透視度の結果を図－3に 示す. サポニン添加後, 透視度は低下していき, 3 月 4 日には12まで悪化したが，その後急速に回復してい る.一般にサポニンを添加すると, 付着したり沈殿し ていた污泥が浮上するなど污泥の性状が変化する時期 が認められることが多いが, 本実験では添加後約 1 力 月がこの期間にあたっているものと思われる.

処理水のCODの結果を図ー 4 に示す。実験期間中

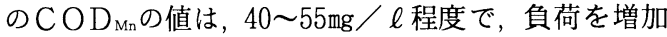
した場合もとくに水質が悪くなる傾向は認められない. むしろ，実験後半の方が前半より安定して若干水質が

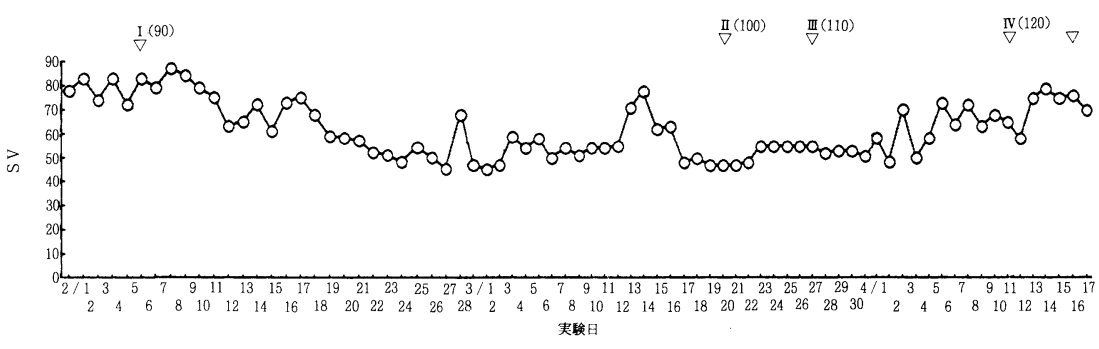

図－2ＳＳの経日変化

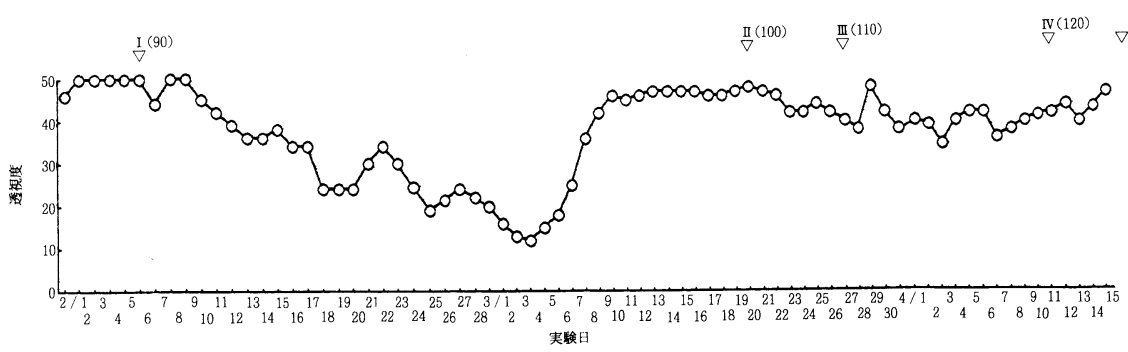

図-3 処理水透視度の経日変化 


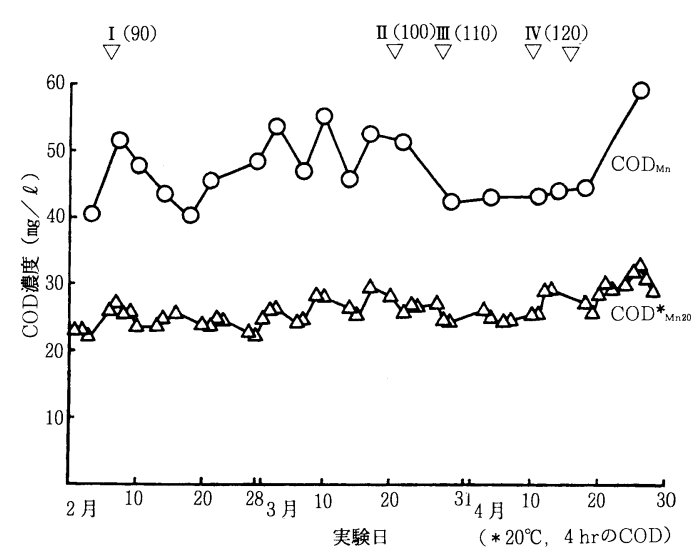

図 -4 処理水 CODの変化

よくなる傾向がみられた.

これまで, 湿式酸化処理水量として $50 \sim 90 \mathrm{~m}^{3} /$ 日程 度で運転を行うことが多く，これ以上の負荷をかける と水質や污泥の状況が悪化し，正常な運転ができなく なったが，本実験においては，過負荷の条件下におい ても安定した処理が可能となっており，サポニン添加 の効果が確認できた，なお，実験期間中の湿式酸化処 理水の $\mathrm{COD}_{\mathrm{Mn}}$ の值については，およそ $1,200 〜 1,500$ $\mathrm{mg} / \ell$ 程度で大きな変動はなかった．

また実験期間中, 最終沈殿池において, 污泥界面の 上昇が認められず，微細な污泥粒子の巻き上げ現象も かなり減少するなど, 最終沈殿池の污泥の性状が変化 したことが認められた.一般に，し尿処理施設の最終 沈殿池においては，常に微細な污泥粒子が流出し，水 の色も黄色く濁っている場合がある. 本実験において あ, 実験開始前の沈殿池はこのような状況に近かった が，実験期間においては下水処理場の最終沈殿池と同 様な透明感のある状況に変化し, サポニン添加の顕著 な効果が認められた.

ただし, 通常70〜80 $\mathrm{m}^{3} /$ 日の余剩污泥が発生するが，
この余剰污泥量については減少する傾向は認められな かった。

\section{3．Fし尿処理施設に関する実験}

$\mathrm{F}$ し尿処理施設は生し尿 $60 \mathrm{k} \ell /$ 日，浄化槽污泥 $40 \mathrm{k} \ell$ ／日の処理能力を有し, 生し尿と浄化槽污泥とは処理 系統が別となっており, 生し尿は高負荷処理法で, 浄 化槽污泥については活性污泥法で処理されている. 近 年投入量が増加し, とくに浄化槽污泥量が増加してき ており, 処理能力以上の負荷をかけざるをえない状況 となってきている. 通常, $40 \mathrm{k} \ell /$ 日の処理能力以上の 負荷をかけると処理状況が悪化し, 正常な処理が続け られなくなるが, サポニンを添加することによって, 過負荷の状況での処理が可能かどうかについて検討を 行ったあのである.

実験開始後, 約 2 力月で安定な状況となり，正常な 処理状況が確認されたが，この間の概要についてはす でに報告した ${ }^{3) 4}$. その後む安定な処理を続けている が，さらに原水希釈率の削減などを行い，污泥量など について検討した。

\section{1 Fし尿処理施設の概要}

F し尿処理施設における浄化槽污泥の処理フローを 図ー 5 に示す.スクリーンされた浄化槽污泥は，6〜 10倍に希釈され, 活性污泥処理される. 活性污泥処理 水は塩化第二鉄, 水酸化ナトリウムによる凝集沈殿, および, 砂ろ過の後, 放流される. サポニン添加実験 を行う前の平均的な処理状況は, 浄化槽污泥投入量約 $40 \mathrm{k} \ell /$ 日，希釈水量約200～360k / 日, ML S S 約 4,000 $m g / \ell$, 余剩污泥引き抜き量約 $30 \mathrm{~m}^{3} /$ 日であった。 また, $40 \mathrm{k} \ell /$ 日以上の負荷量となった場合には，沈殿槽の污泥 の状況が悪化し, 水質むかなり悪化するのが常であった.

\section{2 サポニン添加実験}

\section{(1)実験方法}

サポニン添加は, 曝気槽流入部において流入水量に

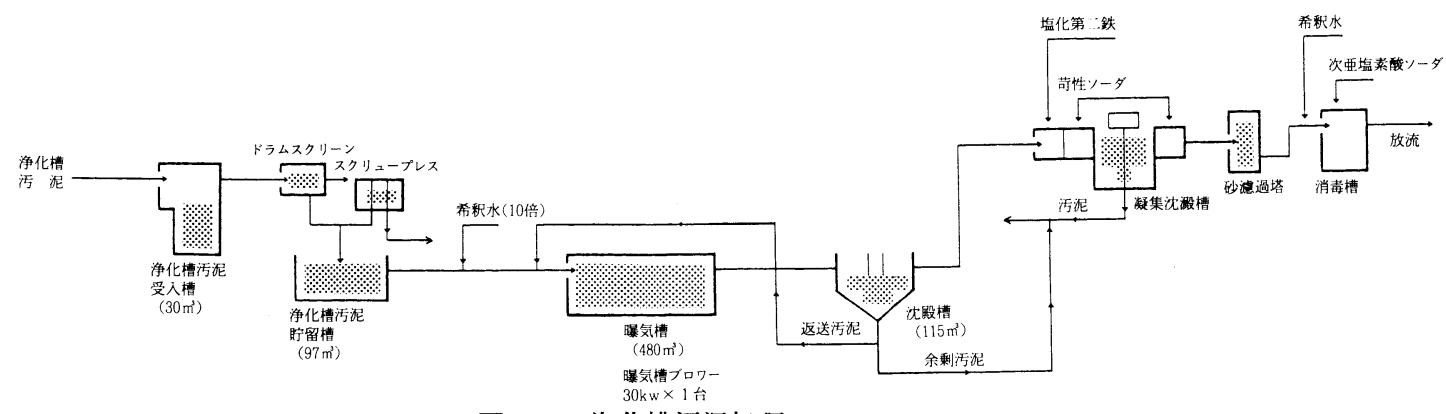

図－5 浄化槽污泥処理フローシート 
対して $2 \mathrm{mg} / \ell$ となるよう定量ポンプで行った. 実験 は1988年 2 月より開始したが，すでに報告したように， 約 2 カ月で安定した処理状況となり, ML S S 濃度の 上昇がみられ，投入負荷量の増加が可能であることが 確認されている.

その後, 7 月 7 日より希釈水量を減少させ， $6 \sim 10$ 倍希釈を 2 倍希釈とした。 また, サポニンの添加率は 状況を見ながら 8 月，9月には 4〜 $5 \mathrm{mg} / \ell$ に増加し たが，その後10月から翌年 3 月にかけて $2 \mathrm{mg} / \ell$ から $1 \mathrm{mg} / \ell$ へと隇少した.

\section{(2)実験結果}

1988年 6 月から1989年 3 月における投入污泥量およ び余剰污泥量の月平均値を図- 6 に示す. 投入污泥量

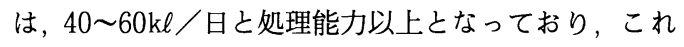
にともない余剩污泥量す推移している. 実験開始以前

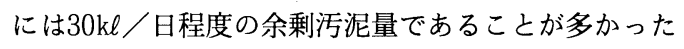

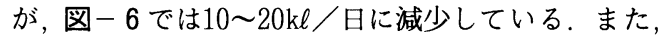
投入污泥量に対する余剩污泥量の比率は， 5 割程度か ら 2 割程度に減少してきている.

曝気槽のM L S S 濃度および沈殿槽から流出する処 理水の S S 濃度を図一 7 に示す. M L S S 濃度は10,0 $00 \mathrm{mg} / \ell$ 程度と高い値となってきているのに対し, 処 理水の濃度は, 低希釈倍率とした 7 月以降徐々に低下 し, $20 \mathrm{mg} / \ell$ に近い值まで減少してきている.

9 月29日における投入污泥の B OD濃度測定結果は

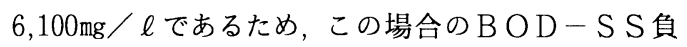
荷率は0.08 $(\mathrm{kg} / \mathrm{kg} ・$ day $)$, B O D - 容積負荷率は $0.71\left(\mathrm{~kg} / \mathrm{m}^{3} \cdot \mathrm{d}\right.$ ay $)$ とかなり高い值となっている.

薬剤の添加量について, 表 3 に示す. サポニン添加 前には, 沈殿槽において污泥の膨化, 流出がみられた ため直接沈殿槽に $2.4 \mathrm{~kg} /$ 日程度の凝集剤を添加していた が，5月以降はこのような現象は認められなくなり，

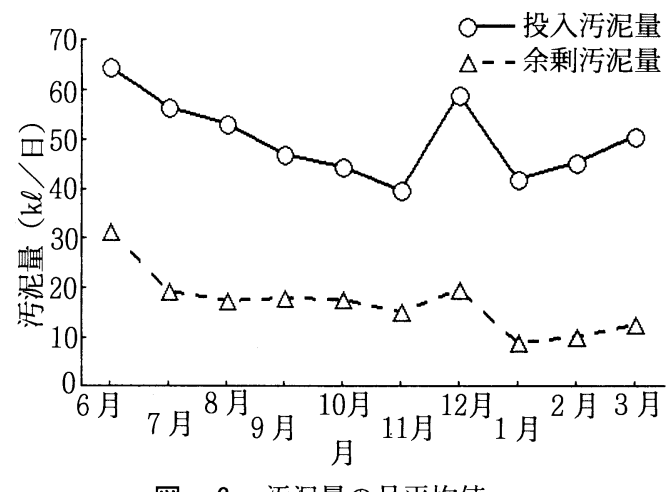

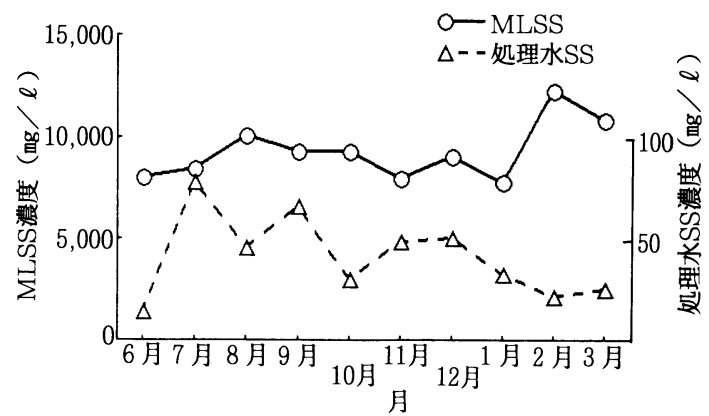

図－7 MLSS，処理水SSの変化

表 3 薬剤添加量

\begin{tabular}{r|ccc}
\hline \multicolumn{1}{c|}{ 年 月 } & $\begin{array}{c}\text { 凝集剤量 } \\
(\mathrm{kg} / \mathrm{日})\end{array}$ & $\begin{array}{c}\mathrm{NaOH} \text { 溶液量 } \\
(\ell / \mathrm{日})\end{array}$ & $\begin{array}{c}\mathrm{FeCl}_{3} \text { 溶液量 } \\
(\ell / \text { 日 })\end{array}$ \\
\hline 1987年11月 & 2.4 & 325 & 302 \\
12月 & 2.4 & 292 & 275 \\
1988年1月 & 2.4 & 301 & 244 \\
2月 & 2.4 & 286 & 247 \\
3月 & 2.0 & 242 & 218 \\
4月 & 0.8 & 294 & 268 \\
5月 & 0 & 282 & 268 \\
6月 & 0 & 229 & 323 \\
7月 & 0 & 188 & 264 \\
8月 & 0 & - & - \\
9月 & 0 & 234 & 238 \\
10月 & 0 & 250 & 230 \\
11月 & 0 & 248 & 218 \\
12月 & 0 & 258 & 244 \\
\hline
\end{tabular}

添加する必要がなくなった，凝集沈殿槽における水酸 化ナトリウム溶液添加量は, $300 \ell /$ 日程度であった あのが $250 \ell /$ 日以下に減少し, 塩化第二鉄溶液む変 動はみられるが減少の傾向が認められた。

以上のごとく，過負荷の条件下においても，サポニ ン添加によって, ML S S の增加, 処理効率の向上, 余剩污泥量の減少, 凝集剤の削減が可能であることを 1 年以上にわたり確認できた.

\section{4. ま と め}

2 つのし尿処理施設において, 通常の処理負荷量の 限界を越えた負荷をかけた場合のサポニン添加の効果 について，実施設での検討を行った結果，実験を行っ た負荷量の範囲では正常な処理を続けることが可能で 
あることを確認できた. 特に, 污泥の沈降性がよくなっ たり, 余㮃污泥量が減少するなど污泥の性状の变化が 顕著に認められた。 また，処理水質は悪化することな く, 通常もしくはそれ以上の処理が可能であることが 確認できた.

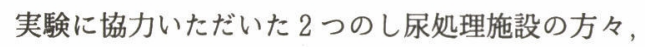
および，試料提供などで協力いただいた(侏駿河エンバ イロメント代表取締役池田正明氏に感謝の意を表しま す.

\section{参考 文 献}

1 ) 蟹江照行 : サポニンの生物処理への応用, P PM, 17(10), $28-33(1986 / 10)$.

2 ) 岩井重久他 : 合成排水の処理におけるサポニン添加の効 果に関する研究, 土木学会第43回年次学術講演会（昭和 63年10月).

3) 岩井重久他 : 活性污泥法におけるサポニン添加の効果 ( I ), P PM, 19 (12), 10-17 (1988/12).

4 ) 岩井重久他 : サポニン添加による生物処理法の活性化, 第26回下水道研究発表会講演集 (平成元年 5 月).

5 ) 岩井重久他：活性污泥法におけるサポニン添加の効果 (II), P PM, 20(4), 18-23 (1989/4).

\section{製品ニュース}

\section{酵母による廃水処理}

\section{酵母処理に向く廃水}

酵母は従来，味増，酱油，ビール等の醸造工業に使 われているように, 高濃度基質や高負荷運転に対応で き，高塩分や高油脂分に耐えられる微生物である。

酵母は分類学上, 真菌類に属し, 活性污泥を構成し ている細菌類とは基本的に異なる。 その為に活性污泥 では分解が困難な基質や活性污泥には毒物として作用 する物質を容易に分解したり，耐性をむっていたりす る.この点を利用して対象廃水を選択すれば, 酵母処 理は優位に立てる。ささらに，酵母処理プロセスから排 出される余剩酵母は, 蛋白質やビタミン等の有効成分 が多いので, 飼料や肥料, あるいはキノコ栽培等に再 利用できる。この場合, 安全性を考えると食品工場廃 水に限られるだろう。

廃水濃度, 基質やpH, 殺菌剂等の問題を含めた食 品工場廃水, 抗生物質やシアン化合物を含有していて, 全く活性污泥法が成り立たない製薬工場廃水等の処理 に適している.

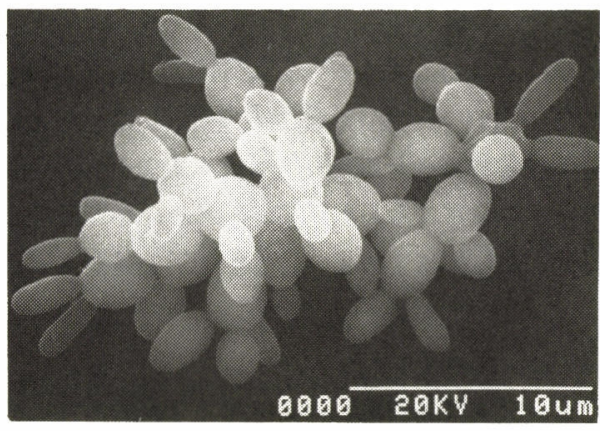

(株)西原環境衛生研究所

該当廃水

・濃度は高い方が良い

・SSは少ない方が良い

・pHは低い方が良い

・ $\mathrm{Cl}^{-}$は高くても良い

- $\mathrm{Cl}^{2}, \mathrm{CN}$, 抗生物質を含有していても良い

・n一hexan抽出物質を含有していてあ良い（鉱物油 はダメ)

\section{具体例}

（1）炭水化物系廃水

製パン工場廃水, 清涼飲料水廃水 (コカコーラ), 製菓工場廃水, ビール工場廃水

（2）蛋白質系廃水 八厶工場廃水

（3）脂質系廃水 ラーメン廃水, 水産加工廃水

(4) その他 漬物廃水, 海水希釈廃水, 味付廃水, 製薬廃水 酵母処理のメリット

（1）高負荷運転が可能であから，容積が小さくなる

(2) DOを必要としないので, 省エネルギーである

(3) 酵母生成量が活性污泥にくらべて極端に少ないの で，污泥処分費が安くなる

（4）余鄱酵母は有効成分が多いので，キノコ栽培，飼 料等に利用できる

（5）酵母は, 活性污泥による処理が難しい廃水の処理 が可能である

[問合せ先] (株)西原環境衛生研究所技術開発部 TEL $03-455-4821$ 